\title{
Az indociánzöld-fluoreszcencia hasznosítása az emlőrák miatt végzett őrszemnyirokcsomó-biopsziában
}

\author{
Venczel László dr. ${ }^{1}$ - Maráz Róbert dr. ${ }^{1,2}$ - Ambrózay Éva dr. ${ }^{3}$ \\ Cserni Gábor dr. ${ }^{4,5}$. Sikorszki László dr. ${ }^{1}$ \\ ${ }^{1}$ Bács-Kiskun Megyei Kórház, a Szegedi Tudományegyetem Általános Orvostudományi Kar Oktató Kórháza, \\ Általános Sebészeti Osztály, Kecskemét \\ ${ }^{2}$ Bács-Kiskun Megyei Kórház, a Szegedi Tudományegyetem Általános Orvostudományi Kar Oktató Kórháza, \\ Onkoradiológiai Központ, Kecskemét \\ ${ }^{3}$ MaMMa Egészségügyi Zrt. Kecskeméti Centrum, Kecskemét \\ ${ }^{4}$ Bács-Kiskun Megyei Kórház, a Szegedi Tudományegyetem Általános Orvostudományi Kar Oktató Kórháza, \\ Patológiai Osztály, Kecskemét \\ ${ }^{5}$ Szegedi Tudományegyetem, Általános Orvostudományi Kar, Patológiai Intézet, Szeged
}

\begin{abstract}
Bevezetés: Napjainkban az őrszemnyirokcsomó felkeresésének legelterjedtebb módszere a radioizotópos és kék festékes kettős jelölés, emellett azonban több más jelölés is alkalmazható. Az indociánzöld-fluoreszcencia ígéretes nyirokút-térképezési módszer, mely a találati arányát tekintve - irodalmi adatok alapján - összevethető a radioizotópos módszerrel.

Módszer: Osztályunkon 2020. 03. 31. és 2020. 04. 15. között 10, emlőrák miatt operált betegünknél alkalmaztuk az indociánzöld és a kék festékes kettős jelölés módszerét az őrszemnyirokcsomó felkeresésére.

Eredmények: A 10 operált betegünknél összesen 17 őrszemnyirokcsomót azonosítottunk és távolítottunk el. 16 őrszemnyirokcsomó jól festődött indociánzölddel (találati arány: 0,94; 95\%-os konfidenciaintervallum [CI ]: 0,730,99), míg kék festékkel 9 jelölődött (találati arány: 0,53; 95\%-os CI: 0,31-0,74). A szövettani feldolgozás során összesen 2 őrszemnyirokcsomó bizonyult áttétesnek, ezek közül 1 kék és fluoreszcens volt, l pedig csak kék festékkel jelölődött.

Következtetés: Kezdeti, kis esetszámnál nyert tapasztalataink alapján az indociánzöld jelölés emlőrák során végzett őrszemnyirokcsomó-biopszia esetén jól használható kettős jelölési módszer részeként, kék festékkel kiegészítve. A módszer találati aránya, valamint fals negatív aránya irodalmi adatok alapján nem különbözik szignifikánsan a radioizotópos jelölés módszerétől.
\end{abstract}

Orv Hetil. 2021; 162(8): 293-297.

Kulcsszavak: emlőrák, őrszemnyirokcsomó-biopszia, indociánzöld

\section{The role of indocyanine green fluorescence in sentinel lymph node biopsy for breast cancer}

Introduction: The current practice in sentinel lymph node biopsy for breast cancer is the radioisotope and blue dye dual labelling technique, however, other mapping methods are also available. Indocyanine green fluorescence is one of the best alternatives of the standard technique, with detection rates comparable to those of the radioisotope method.

Method: Between 31. 03. 2020 and 15. 04. 2020, a total of 10 sentinel lymph node biopsies for breast cancer were performed using the indocyanine green fluorescence and blue dye dual technique.

Results: 17 sentinel lymph nodes were detected and removed in total, from which 16 showed explicit fluorescence activity (detection rate: $0.94 ; 95 \%$ confidence interval [CI]: $0.73-0.99$ ), whilst 9 where blue (detection rate: 0.53 ; 95\% CI: 0.31-0.74). During histopathological examination, 2 sentinel lymph nodes proved to be metastatic, from which 1 was fluorescent and blue, the other was blue only. 
Conclusion: Regarding our early experience based on a small number of patients, indocyanine green fluorescence, used together with blue dye as part of a dual technique, is a usable method for sentinel lymph node mapping. Based on data from the literature, the detection rate and the false-negative rate of the indocyanine green fluorescence method shows no significant difference from the radioisotope mapping technique.

Keywords: breast cancer, sentinel lymph node biopsy, indocyanine green

Venczel L, Maráz R, Ambrózay É, Cserni G, Sikorszki L. [The role of indocyanine green fluorescence in sentinel lymph node biopsy for breast cancer]. Orv Hetil. 2021; 162(8): 293-297.

(Beérkezett: 2020. július 18.; elfogadva: 2020. szeptember 17.)

\section{Rövidítések}

ALND = axillaris lymphadenectomia; $\mathrm{BD}=($ blue dye $)$ kék festék; $\mathrm{CI}=($ confidence interval $)$ konfidenciaintervallum; ICG $=$ indociánzöld; $\mathrm{RI}=$ radioizotóp; SLN = (sentinel lymph node) őrszemnyirokcsomó; SLNB = (sentinel lymph node biopsy) őrszemnyirokcsomó-biopszia

A hónalji nyirokcsomóstatus régóta a korai emlőrák egyik legfontosabb prognosztikai tényezője. Bár a korábban rutinszerúen alkalmazott axillaris lymphadenectomia (ALND) mára háttérbe szorult az őrszemnyirokcsomó (SLN)-elmélet térhódítása következtében, ez a sebészi módszer a mai napig a legpontosabb a hónalji nyirokcsomóstatus megítélésére. A rutinszerúen alkalmazott ALND elhagyását a módszerrel kapcsolatos hoszszú távú szövődmények - vállövi mozgáskiesés, érzéskiesés, nyiroködéma -, valamint az egyre ritkábbá váló hónalji áttétes nyirokcsomók tették szükségessé. Az 1990-es évek első felében Krag és mtsai, valamint Giuliano és mtsai igazolták, hogy emlőrák esetén az őrszemnyirokcsomó-biopszia (SLNB) alkalmas a hónalji nyirokcsomóstatus megítélésére, és kisebb a morbiditása, mint a gyakran túlkezelésnek bizonyuló ALND-nek [1, 2]. Bár a módszer első leírói csak radioizotópot (RI), illetve csak kék festéket (blue dye, BD) használtak a nyirokúttérképezéshez, napjainkban széles körben a radioizotópos ( $\left.{ }^{99 \mathrm{~m}} \mathrm{Tc}\right)$ és vitális kék festékes kettős jelölési módszer $(\mathrm{RI}+\mathrm{BD})$ terjedt el, melynek első leírása Albertini és mtsai nevéhez füződik [3]. Az RI + BD módszer lényege, hogy a két jelölési módszer előnyeit társítva, nagyobb találati arányt biztosít az egyes jelölési módszerekhez képest $[4,5]$.

Annak ellenére, hogy napjainkban a legelterjedtebb, és hazánkban is standard eljárásként elfogadott és javasolt módszer az RI + BD [6], mégsem tekinthetó optimális megoldásnak, hiszen számos előnye mellett néhány hátránya is van. Az RI viszonylag költséges módszer, izotópdiagnosztikai hátteret igényel állandó izotópellátással, a nyirokutakat nem jelöli, csak dinamikus vizsgálat esetén, valamint hónaljközeli izotópbeadás esetén nehézkes lehet az SLN felkeresése. A BD olcsó, de találati aránya elmarad az RI-étől, valamint allergiás reakciók is előfordulnak. A fentiek miatt folyamatos útkeresés zajlik az op- timális jelölési módszer kidolgozására. Ezen munkák eredményeként jelentek meg újabb módszerek az SLN azonosítására, mint az indociánzöld (ICG)-fluoreszcencia, a szuperparamágneses vas-oxid-nanorészecskék, valamint a mikrobuborékokat tartalmazó kontrasztanyagos ultrahang.

A számos jelölési módszer közül a legtöbb szerző az ICG-fluoreszcencia módszerét tartja a leginkább alkalmazhatónak. Az indociánzöld alacsony molekulasúlyú, szerves molekula, mely a plazmafehérjékhez kötődik, és a közeli infravörös tartományban fluoreszkál. Lézeraszszisztált kamerával az SLN-ben és a nyirokutakban felhalmozott, fluoreszkáló festék láthatóvá tehető, ezáltal valós idejü limfangiográfia végezhető. Emlőrák esetén a nyirokutak és az SLN megjelenítésére Kitai és munkacsoportja alkalmazta elöször 2005-ben [7].

$\mathrm{Az}$ irodalmi adatokra, valamint saját, hasi sebészet kapcsán ICG-fluoreszcenciával szerzett korábbi tapasztalatunkra támaszkodva, az izotópdiagnosztikai részleg ideiglenes, előre nem látható tartamú bezárása alatt kezdtük el osztályunkon az indociánzöld és kék festékes kettős jelölést (ICG + BD) SLNB során.

\section{Módszer}

Osztályunkon 2020. 03. 31. és 2020. 04. 15. között SLNB-ra is előjegyzett emlőrákos betegeknél alkalmaztuk az ICG + BD kettős jelölés módszerét. Az adatok feldolgozása retrospektív módon történt, az ehhez szükséges adatkezelési engedélyt az intézeti adatvédelmi biztostól kaptuk. Az adatok kigyújtését követően anonimizált adatok kerültek elemzésre.

Az általunk használt ICG festék a Verdye ${ }^{\mathrm{TM}}$ (Diagnostic Green GmbH, Aschheim-Dornach, Németország) volt; megjelenítőeszközként a Visionsense $\mathrm{VS}_{3}$ Iridium rendszert használtuk, mely az EleVision ${ }^{\mathrm{TM}}$ IR Platform (Medtronic plc, New Haven, CT, Amerikai Egyesült Államok) része.

A $25 \mathrm{mg}$ Verdye $^{\mathrm{TM}}$ festéket $20 \mathrm{ml}$ steril desztillált vízben oldottuk fel. Az oldatból 1-2 ml-t a mútét kezdete elött 10 perccel az areola alá subdermalisan fecskendeztük be 4 depóban. Az ICG beadásával egy időben, szintén az areola alá, subdermalisan, 4 depóban adtunk be 
$1 \mathrm{ml}$ BD-t (Blu Patent V 2,5\%, S.A.L.F. S.p.A. Laboratorio Farmacologico, Cenate Sotto, Olaszország), ami megfelelt az osztályunkon rutinszerüen alkalmazott eljárásnak. A beadást követóen az areola felől az axilla irányába tartó, enyhe masszázst végeztünk $[8,9]$.

A mütétet minden esetben az SLNB elvégzésével kezdtük, és ezt követte az emlő mútéte. A megjelenítő-

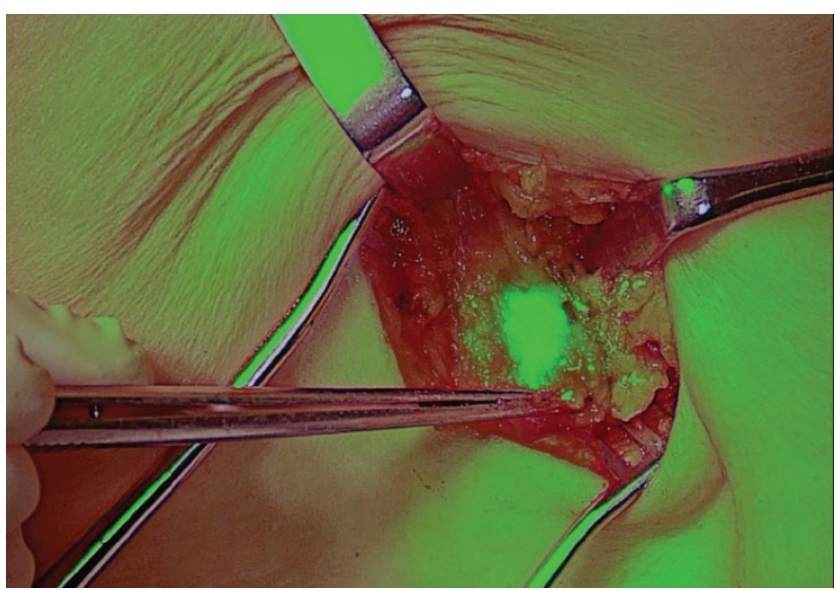

1. ábra

A fluoreszkáló őrszemnyirokcsomó jól elkülönül a környezó zsírszövettől

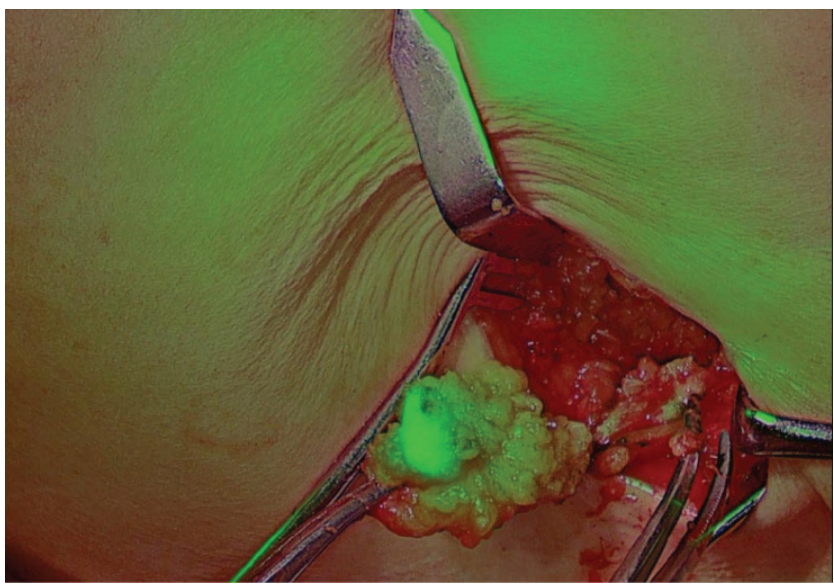

2. ábra $\mid$ Az őrszemnyirokcsomó kipreparálása és in vivo ellenőrzése

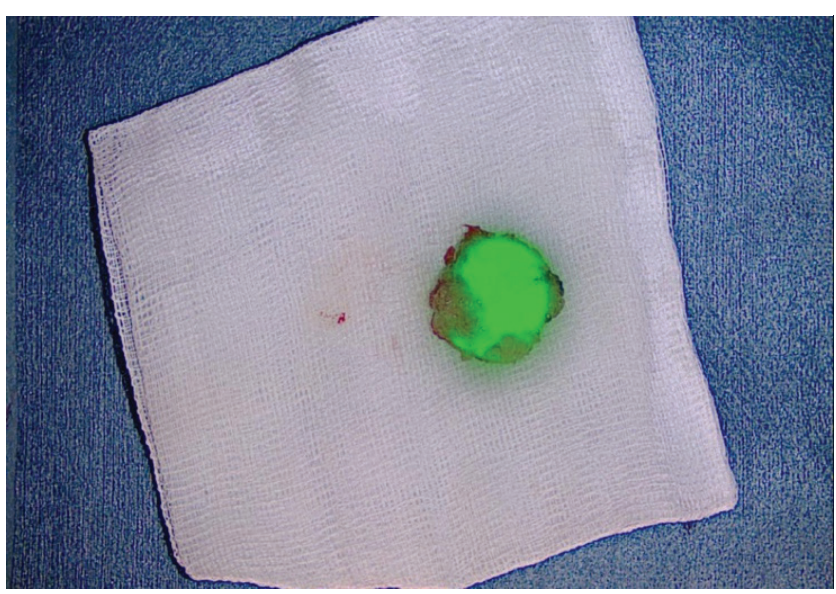

3. ábra eszköz kamerájának segítségével a bőrön látható, az areolától az azonos oldali axillához tartó, fluoreszkáló nyirokutakat steril tollal berajzoltuk, és a 3-6 cm-es axillaris metszést az előzetes bőrjelölést követően ott végeztük el, ahol a nyirokutak látható fluoreszkálása eltűnt [10]. A bőrmetszést követóen elektrokauter segítségével, vértelenül preparáltunk. A subcutis átvágása után a megjelenítőeszköz kameráját használva vizualizáltuk az SNL-hez vezető, fluoreszkáló nyirokutakat, valamint felkerestük a szintén jól látható, erőteljes fluoreszkálást mutató, egy vagy több SLN-t. Mindeközben szabad szemmel ellenőriztük a BD jelenlétét is. Fontos megjegyezni, hogy az általunk használt ICG-fluoreszcenciás vizualizálórendszer esetén a környező zsírszövet is fluoreszkál csekély mértékben, ez azonban pontosan megkülönböztethető a nyirokutak egyértelmú fluoreszkálásától. Az SLN fluoreszkálása minden esetben nagyon határozott, jól elkülöníthető mind vizuálisan, mind számszerüen a környező zsír és a rávezető nyirokutak fluoreszkálásától (1. ábra). Az aktív nyirokcsomót tartalmazó zsírszövetet megragadva, környezetétől kissé előemelve, erőteljesen fluoreszkáló területként azonosíthattuk az SLN-t (2. ábra), melyet az eltávolítást követően, ex vivo is minden esetben megvizsgáltunk, és aktívnak (fluoreszkálónak) találtunk (3. ábra). Minden nyirokcsomót, amely valamelyik jelölési módszerrel ábrázolódott, SLN-nek tekintettünk és eltávolítottunk.

\section{Eredmények}

2020. 03. 31. és 2020. 04. 15. között 10 operált betegünknél összesen 17 SLN-t azonosítottunk és távolítottunk el. Az eltávolított SLN-ek egy kivételével jól festődtek ICG-vel (találati arány: 0,94; 95\%-os konfidenciaintervallum [CI]: 0,73-0,99), míg BD-vel 9 festődött (találati arány: 0,53; 95\%-os CI: 0,31-0,74), ezek egyike ICG-vel nem került azonosításra. Ezen találati arányok - bár a kis esetszám miatt statisztikai következtetéseket levonni nem lehet - megfelelnek az irodalmi adatoknak. A találati arányokkal kapcsolatban további kutatást nem végeztünk.

A szövettani feldolgozás során összesen 2 SLN bizonyult áttétesnek, ezek közül 1 kék és fluoreszcens zöld volt, 1 pedig csak BD-vel jelölődött (1. táblázat). Ezen utóbbi eset érdekessége, hogy összesen 2 SLN került eltávolításra, melyek közül 1 fluoreszcens zöld és kékre festődő is volt (szövettanilag áttétmentes), a másik SLN

1. táblázat |A különböző jelölési módszerek találati aránya

\begin{tabular}{lrlll}
\hline & $\mathrm{n}$ & $\begin{array}{l}\text { Találati } \\
\text { arány }\end{array}$ & $\begin{array}{l}\text { 95\%-os konfidencia- } \\
\text { intervallum }\end{array}$ & $\begin{array}{l}\text { Áttétes } \\
\text { SLN }\end{array}$ \\
\hline SLN összesen & 17 & & & 2 \\
ICG+ & 16 & 0,94 & $0,73-0,99$ & 1 \\
BD+ & 9 & 0,53 & $0,31-0,74$ & 2 \\
\hline
\end{tabular}

BD = kék festék; ICG = indociánzöld; SLN = őrszemnyirokcsomó 
viszont csak BD-vel ábrázolódott - ez a nyirokcsomó szövettanilag metastaticusnak bizonyult.

A betegek átlagéletkora 64,1 év (terjedelem: 42-78 év) volt. Az elvégzett mútétek a következők voltak: 2 quadrantectomia, 2 széles excisio specimen-röntgenvizsgálattal, 4 mastectomia (ezek egyikénél az intraoperatív lenyomatcitológia pozitivitása miatt ALND is történt), 2 széles excisio level I. onkoplasztikus módszerrel.

A mútéti idők 60 és 140 perc között változtak. Az ICG és a BD subareolaris beadása közvetlenül a műtéti terület lemosása és izolálása előtt történt, így a festék beadása és az SLN felkeresésének megkezdése között kb. 10 perc telt el. A mútéti időt az ICG-fluoreszcencia módszerével kapcsolatosan csupán a festék beadása, illetve a vizualizálóeszköz izolálása hosszabbította, ami azonban jelentős, mérhető időveszteséget nem okozott. Az SLN felkeresése során a módszer további időveszteséget nem okoz az egyéb SLN-jelölési módszerekhez képest, de fontos megjegyezni, hogy erre irányuló összehasonlító vizsgálatot nem végeztünk.

Az ICG-eljárással kapcsolatos szövődményt nem észleltünk. Mindegyik betegünk szövődménymentesen gyógyult.

\section{Megbeszélés}

Irodalmi adatok alapján az emlőrák esetén rutinszerúen elvégzett SLNB során a leggyakrabban alkalmazott eljárás az $\mathrm{RI}+\mathrm{BD}$ módszer. Léteznek azonban jelentős törekvések egyéb módszerek kidolgozására, melyek a kettôs jelölés egyik komponensének kiváltásával további hozzáadott értéket képviselnek. Ilyen jelölőmódszer az ICG-fluoreszcencia, amelynek alkalmazásáról számos közlemény, prospektív randomizált vizsgálat, metaanalízis jelent meg. A 2014-ben, Ahmed munkacsoportja által közölt metaanalízis igazolta, hogy az ICG-fluoreszcencia önálló jelölési módszerként alkalmazva szignifikánsan magasabb SLN-találati arányt biztosít a BD-módszerrel összehasonlítva [10]. 2018-ban a Yuan munkacsoportja által, 471 beteg bevonásával elvégzett prospektív randomizált klinikai vizsgálat megállapította, hogy az ICG + $\mathrm{BD}$, illetve az RI + BD kettős jelölési módszerek között nincs szignifikáns különbség a szenzitivitás (94,5\% vs. $92,5 \%)$, valamint a fals negatív arány tekintetében $(5,6 \%$ vs. 7,5\%). A munkacsoport megállapítása szerint az ICG az RI alternatívájaként biztonságosan használható a BDmódszerrel kombinálva [11]. Egy újabb metaanalízis, melyben kohorszvizsgálatok mellett már 4 randomizált klinikai vizsgálat is szerepelt, szintén az ICG hozzáadott vagy alternatív módszerként való alkalmazhatóságát támasztja alá SLN-ek azonosításakor [12]. Ezek értelmében az ICG-módszer magas evidenciaszinttel rendelkezik.

$\mathrm{Az}$ érintett időszakban kórházunkban szünetelt az izotópdiagnosztika a Nukleáris Medicina Osztály átmeneti, kényszer szülte leállása következtében, így a megszokott, RI + BD jelölést nem alkalmazhattuk SLNB során. Munkacsoportunknak a korábban alkalmazott BD egyes jelöléssel kapcsolatban is nagy tapasztalata van, hiszen az SLNB-módszer bevezetésekor évekig ez volt a standard eljárás osztályunkon [13, 14].

A kórházunkban elérhető EleVision ${ }^{\mathrm{TM}}$ IR rendszert rutinszerúen alkalmazzuk egyéb sebészeti területeken (például vastagbél-, végbél-, valamint nyelőcső-reszekciók esetén), így az irodalmi adatok ismeretében, az izotópdiagnosztika hiányában adódott a lehetőség az ICG + BD jelölés használatára SLNB során. 10 esetben végeztük el az SLNB-t ICG + BD kettős jelöléssel, összesen 17 SLN-t azonosítva és eltávolítva.

Az eljárás előnye, hogy a mútétet megelőzően nem igényel előkészületet vagy diagnosztikai osztály igénybevételét, szemben az RI-módszerrel. Az RI-módszerhez hasonlóan, az axillán kívüli SLN, valamint a hozzá vezető nyirokutak a bőrön keresztül vizualizálhatók, bár erre vonatkozóan limitált tapasztalatunk nem irányadó, és nagyon korlátozott az irodalom is. Takeuchi és mtsai 6\%-os arányban említenek detektált arteria (a.) mammaria interna melletti régióba irányuló nyirokút-elvezetést [15], míg Lin és mtsai ennél is kisebb arányban (1/40) észleltek ilyet [16]. Cong és mtsai munkájában az a. mammaria interna SLN-ek különböző jelölőanyag-beadási technikái mellett magas arányban voltak radioaktívak és fluoreszcens zöldek egyaránt, de felfedezésükben a radioaktivitás segített [17]; ebben a régióban a $\mathrm{RI}+\mathrm{BD}$ technika esetén is kisebb a BD szerepe [18]. Az említett anatómiai régiókon (axilla és a. mammaria interna régió) kívüli, például supraclavicularis, ellenoldali axillaris elvezetés leírásáról ICG-technikával nem találtunk adatot. Emiatt az előzetes limfoszcintigráfiához képest az extraanatómiai nyirokelvezetés kimutatásában a módszer nagy valószínűséggel gyengébb, ami felhasználási korlátot is jelenthet, és ami miatt például ismételt SLNB (re-SLNB) [19] céljára a módszer jelenleg nem javasolható.

Az ICG-vizualizálórendszer használata könnyen elsajátítható, speciális jártasságot nem igényel. Bár a kis esetszámból statisztikai következtetéseket nem vonhatunk le, a módszerrel szerzett tapasztalataink igen kedvezőek, az irodalmi adatoknak megfelelnek.

Az ICG festékkel kapcsolatos szövődmények elsősorban a festékkel szembeni allergiás reakciókra korlátozódnak, melyek azonban irodalmi adatok alapján igen ritkák. Hope-Ross és mtsai 1923 eset kapcsán 0,2\%-ban tapasztaltak közepesen súlyos mellékhatást, súlyos mellékhatást pedig 0,05\%-ban [20]. Az Abmed által közölt metaanalízisben 15 vizsgálat 1362 betege közül egy sem mutatott allergiás reakciót [10]. Fontos azonban megjegyezni, hogy a Verdye ${ }^{\mathrm{TM}}$ jódot tartalmaz, ezért jódérzékeny betegnek nem adható.

\section{Következtetés}

Munkacsoportunk kezdeti, kis esetszámon alapuló tapasztalata, valamint az irodalmi adatok alapján az ICGjelölési módszer emlőrák során végzett SLNB esetén jól 
használható, kettős jelölési módszer részeként, kék festékkel kiegészítve (ICG + BD). Találati aránya, valamint fals negatív aránya - az irodalmi adatok alapján - az RI módszerétől nem különbözik szignifikánsan. Amennyiben emlőrák miatt végzett mütétekben jelentős tapasztalattal rendelkező munkacsoport számára ICG-vizualizálóeszköz rendelkezésre áll, javasolható az SLNB során alkalmazni és ezáltal további, hazai tapasztalatot szerezni a módszerrel.

Anyagi támogatás: A kézirat megírása anyagi támogatásban nem részesült.

Szerzői munkamegosztás: V. L.: Irodalomkutatás, a cikk elkészítése. M. R.: A kéziratban szereplő mütétekben nyújtott operatőri munka, kéziratszerkesztés, fotódokumentáció. A. É.: A kéziratban szereplő esetek radiológiai diagnosztikája, szakmai támogatás. Cs. G.: A kéziratban szereplő esetek patológiai feldolgozása, a tudományos feldolgozáshoz és bemutatáshoz nyújtott szakmai segítség, kéziratszerkesztés. S. L.: A kéziratban foglalt mưtétekhez nyújtott szakmai támogatás, folyamatos segítség a kézirat megírásában. A cikk végleges változatát minden szerző elolvasta és jóváhagyta.

Érdekeltségek: A szerzőknek nincsenek érdekeltségeik.

\section{Irodalom}

[1] Krag DN, Weaver DL, Alex JC, et al. Surgical resection and radiolocalization of the sentinel lymph node in breast cancer using a gamma probe. Surg Oncol. 1993; 2: 335-340.

[2] Giuliano AE, Kirgan DM, Guenther JM, et al. Lymphatic mapping and sentinel lymphadenectomy for breast cancer. Ann Surg. 1994; 220: 391-401.

[3] Albertini JJ, Lyman GH, Cox C, et al. Lymphatic mapping and sentinel node biopsy in the patient with breast cancer. JAMA 1996; 276: 1818-1822.

[4] He PS, Li F, Li GH, et al. The combination of blue dye and radioisotope versus radioisotope alone during sentinel lymph node biopsy for breast cancer: a systematic review. BMC Cancer 2016; 16:107.

[5] Goyal A, Newcombe RG, Chhabra A, et al. Factors affecting failed localisation and false-negative rates of sentinel node biopsy in breast cancer - results of the ALMANAC validation phase. Breast Cancer Res Treat. 2006; 99: 203-208.

[6] Lázár Gy, Bursics A, Farsang Z, et al. 3rd Hungarian Breast Cancer Consensus Conference - surgery guidelines. [III. Emlőrák
Konszenzus Konferencia - Az emlórák korszerú sebészi kezelése.] Magy Onkol. 2016; 60: 194-207. [Hungarian]

[7] Kitai T, Inomoto T, Miwa M, et al. Fluorescence navigation with indocyanine green for detecting sentinel lymph nodes in breast cancer. Breast Cancer 2005; 12: 211-215.

[8] Guo J, Yang H, Wang S, et al. Comparison of sentinel lymph node biopsy guided by indocyanine green, blue dye, and their combination in breast cancer patients: a prospective cohort study. World J Surg Oncol. 2017; 15: 196.

[9] Mátrai Z, Gulyás G, Kásler M. Modern surgery of the breast cancer. [Az emlörák korszerű sebészete]. Medicina Könyvkiadó, Budapest, 2015; pp. 139-144. [Hungarian]

[10] Ahmed M, Purushotham AD, Douek M. Novel techniques for sentinel lymph node biopsy in breast cancer: a systematic review. Lancet Oncol. 2014; 15: e351-e362.

[11] Yuan L, Qi X, Zhang Y, et al. Comparison of sentinel lymph node detection performances using blue dye in conjunction with indocyanine green or radioisotope in breast cancer patients: a prospective single-center randomized study. Cancer Biol Med. 2018; 15: 452-460.

[12] Thongvitokomarn S, Polchai N. Indocyanine green fluorescence versus blue dye or radioisotope regarding detection rate of sentinel lymph node biopsy and nodes removed in breast cancer: a systematic review and meta-analysis. Asian Pac J Cancer Prev. 2020; 21: 1187-1195.

[13] Cserni G, Rajtár M, Boross G, et al. Comparison of vital dyeguided lymphatic mapping and dye plus gamma probe-guided sentinel node biopsy in breast cancer. World J Surg. 2002; 26: 592-597.

[14] Cserni G, Boross G, Baltás B. Value of axillary sentinel nodal status in breast cancer. World J Surg. 2000; 24: 341-344.

[15] Takeuchi M, Sugie T, Abdelazeem K, et al. Lymphatic mapping with fluorescence navigation using indocyanine green and axillary surgery in patients with primary breast cancer. Breast $\mathrm{J}$. 2012; 18: 535-541.

[16] Lin J, Lin LS, Chen DR, et al. Indocyanine green fluorescence method for sentinel lymph node biopsy in breast cancer. Asian J Surg. 2020; 43: 1149-1153.

[17] Cong BB, Qiu PF, Liu YB, et al. Validation study for the hypothesis of internal mammary sentinel lymph node lymphatic drainage in breast cancer. Oncotarget 2016; 7: 41996-42006.

[18] Maráz R, Boross G, Pap-Szekeres J, et al. Internal mammary sentinel node biopsy in breast cancer. Is it indicated? Pathol Oncol Res. 2014; 20: 169-177.

[19] Sávolt A, Cserni G, Lázár G, et al. Sentinel lymph node biopsy following previous axillary surgery in recurrent breast cancer. Eur J Surg Oncol. 2019; 45: 1835-1838.

[20] Hope-Ross M, Yannuzzi LA, Gragoudas ES. Adverse reactions due to indocyanine green. Ophthalmology 1994; 101: 529-533.

(Venczel László dr., Kecskemét, Nyíri út 38., 6000 e-mail: drvenczel@gmail.com)

A cikk a Creative Commons Attribution 4.0 International License (https://creativecommons.org/licenses/by/4.0/) feltételei szerint publikált Open Access közlemény, melynek szellemében a cikk bármilyen médiumban szabadon felhasználható, megosztható és újraközölhetö, feltéve, hogy az eredeti szerző és a közlés helye, illetve a CC License linkje és az esetlegesen végrehajtott módosítások feltüntetésre kerülnek. (SID_1) 